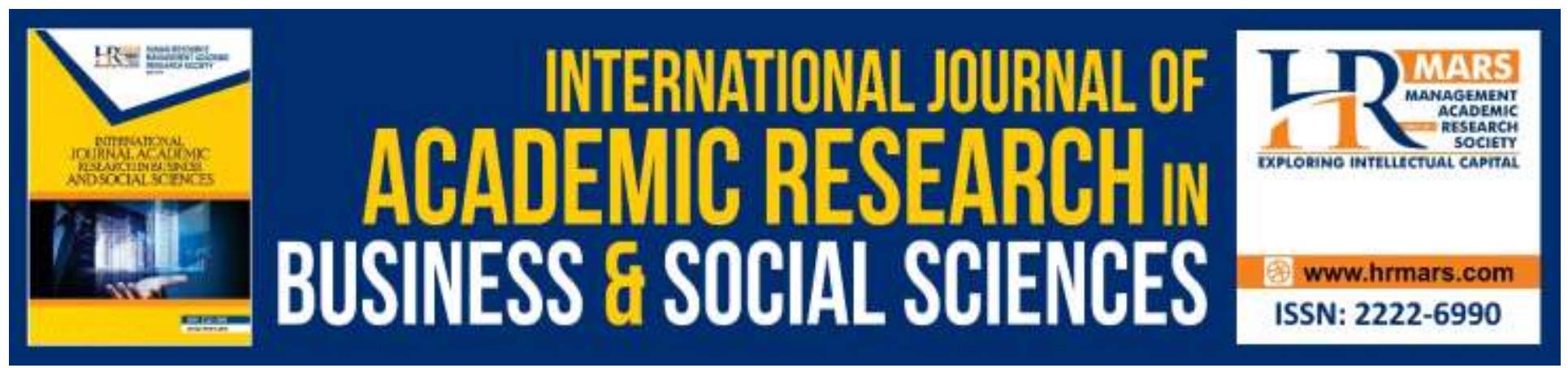

\title{
Determinants of Internal Corporate Social Responsibility Practices and Employee Engagement: A Study of Malaysian Private Higher Education Institution
}

Tak Jie Chan, Md. Monir Hossen, Nurul Ain Mohd Hasan

To Link this Article: http://dx.doi.org/10.6007/IJARBSS/v10-i5/7231

DOI:10.6007/IJARBSS/v10-i5/7231

Received: 12 March 2020, Revised: 15 April 2020, Accepted: 27 April 2020

Published Online: 21 May 2020

In-Text Citation: (Chan et al., 2020)

To Cite this Article: Chan, T. J., Hossen, M. M., \& Hasan, N. A. M. (2020). Determinants of Internal Corporate Social Responsibility Practices and Employee Engagement: A Study of Malaysian Private Higher Education Institution. International Journal of Academic Research in Business and Social Sciences, 10(5), 575-590.

Copyright: (c) 2020 The Author(s)

Published by Human Resource Management Academic Research Society (www.hrmars.com)

This article is published under the Creative Commons Attribution (CC BY 4.0) license. Anyone may reproduce, distribute, translate and create derivative works of this article (for both commercial and non-commercial purposes), subject to full attribution to the original publication and authors. The full terms of this license may be seen

at: http://creativecommons.org/licences/by/4.0/legalcode

Vol. 10, No. 5, 2020, Pg. 575 - 590

http://hrmars.com/index.php/pages/detail/IJARBSS

JOURNAL HOMEPAGE

Full Terms \& Conditions of access and use can be found at http://hrmars.com/index.php/pages/detail/publication-ethics 


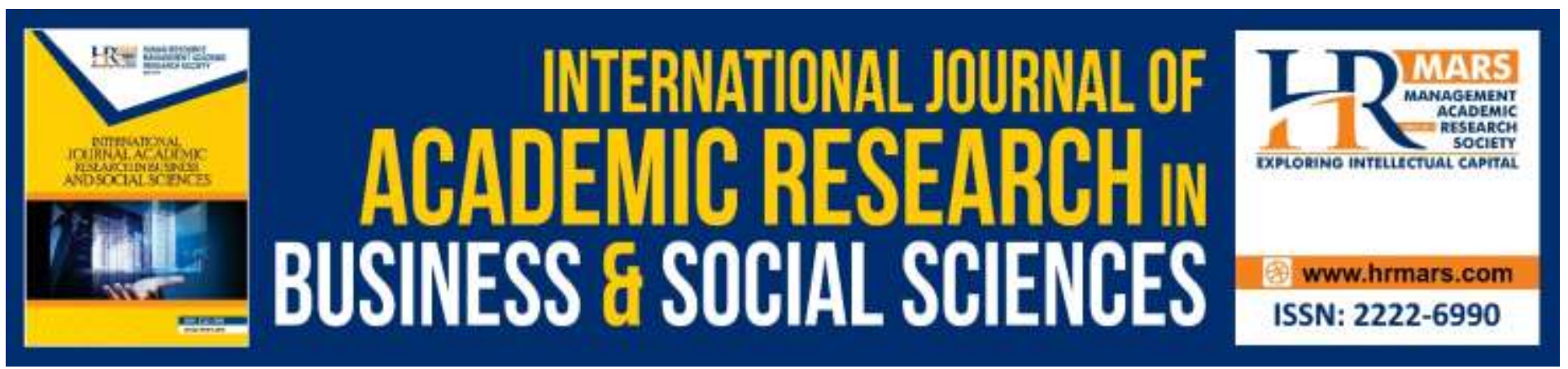

\title{
Determinants of Internal Corporate Social Responsibility Practices and Employee Engagement: A Study of Malaysian Private Higher Education Institution
}

\author{
Tak Jie Chan, Md. Monir Hossen \\ Faculty of Business, Social Sciences \& Hospitality Management, SEGi University, 47810, Petaling \\ Jaya, Selangor \\ Email: chantakjie@segi.edu.my, monir.hossen301@gmail.com
}

\begin{abstract}
Nurul Ain Mohd Hasan
Faculty of Modern Languages and Communication, Universiti Putra Malaysia, 43400, UPM Serdang, Selangor

Email:namh@upm.edu.my
\end{abstract}

\begin{abstract}
Corporate Social Responsibility (CSR) has emerged tremendously as an important field of study. However, the influence of internal corporate social responsibility (ICSR) practices in education industry remain understudied. The purpose of this study was to investigate the relationship between ICSR practices and employee engagement in a private university in Malaysia. A quantitative (survey) method was employed using purposive sampling in which 93 valid responses were generated. The data were then analyzed using Pearson-Product Moment Correlation and Multiple Regression test through the Statistical Package for the Social Sciences (SPSS) version 25.0. Based on the findings, ICSR dimensions, namely training \& education and working environment yielded positive and moderate relationships with employee engagement, whereas employment stability and employee empowerment generate positive and high relationships with employee engagement. In addition, multiple regression analysis showed that employment stability and training \& education were the significant two predictors that can help to increase the employee engagement. Conclusion, implications, and suggestions for future studies are also discussed.

Keywords: Education Industry, Employee Engagement, Employee Relations, Internal Corporate Social Responsibility, Organizational Behaviour.
\end{abstract}

\section{Introduction}

Corporate social responsibility (CSR) has gained an interest in the higher education institutions (HEIs) (Bakar \& Ismail, 2019; Chan \& Hasan, 2018; Hasan, 2017). Of late, HEls are more likely than ever to 
produce a holistic human capital to achieve the nation's sustainable goals, which supports the notion stated by Chang, Sirat, and Abdul Razak, (2018) that human capital plays a vital role for continued prosperity in the future.

According to The Star (2018), Malaysia aims to be an educational hub for international students in the Asian regions with the target of 200,000 international students in Malaysia by the year 2020 and 250,000 by 2025 . Hence, in order to gain competitive advantage it requires talented and committed workforce. Gao (2019) and Low (2020) highlighted that practicing internal corporate social responsibility (ICSR) can help to strengthen the employee engagement in the institutions. Thus, by practicing the determinants of ICSR, it will provide new insights to achieve the goals of the education industry.

There is a pressing issue with high turnover rate of employees, particularly the academic staff in the Malaysian higher education setting (Manogharan, Thivaharan, \& Abd Rahman, 2018; Rathakrishnan, $\mathrm{Ng}$, \& Tee, 2016; Saraih, Aris, Sakdan, Ahmad, 2017). This is also congruent with the findings of Ranjan \& Yadav (2018) who found out that the turnover rate in the education industry is higher compared to other industries. Often times, the high turnover resulted in organizations incurring more cost to train newly hired staff and as a result, the institutions potentially lacks long term loyalty and engagement with employees. This further supported the notion of Ramasamy and Abdullah (2017) where employee disengagement in the universities may result in loss of progress for the institutions. Despite the issue that has been frequently highlighted in the mass-media and government official reports, empirical studies on employee engagement are still limited in developing countries (Bailey, Madden, Alfes, \& Fletcher, 2017) and studies on the HEls require further investigation (Pham-Thai, McMurray, Muenjohn, \& Muchiri, 2018).

From the theoretical perspective, social exchange theory (SET) is considered appropriate to this study as it explains the reciprocal relationship between ICSR activities and employee engagement (Azmin, 2016; Slack, Corlett, \& Morris, 2015; Zulfiqar, Sadaf, Popp, Vveinhardt \& Máté, 2019). In other words, the ICSR practices are the basis of exchange, which the HEls use to gauge the positive social exchange interactions. Based on the voids highlighted above, this study aims to find out the predicting factors of ICSR practices (Training and Education, Working Environment, Empowerment, Employment Stability) and employee engagement in a Malaysian private HEl.

\section{Literature Review}

Definitions of ICSR

ICSR practices refer to the concern by companies towards their employees in terms of physical and psychological aspects. ICSR includes policies and guidelines that can improve the physical environment such as workplace which is free from risks. Some initiatives of ICSR range from empowerment, such as evaluating their decisions and priorities, to work-life balance, such as flexibility, vacations (Cavazotte \& Chang, 2016). Furthermore, Mory, Wirtz, and Göttel (2015) characterized that ICSR has four dimensions which include, education and training, empowerment, stability, and working environment. 
INTERNATIONAL JOURNAL OF ACADEMIC RESEARCH IN BUSINESS AND SOCIAL SCIENCES

Vol. 10, No. 5, May, 2020, E-ISSN: 2222-6990 @ 2020 HRMARS

\section{Dimension of ICSR Practices}

Training and education encompass the process, actions, and activities that are prepared for improving employee's skills, knowledge, and attitudes. In the same vein, Pelochino (2017) highlighted that, training and development is a strategic and planned way to achieve the goals of an institution. In summary, it is the combination of different activities to build a matrix of beliefs, increase skills, and finally, to motivate employees to perform better in their workplace.

Employee empowerment means to delegate power from employers to employees. Curran (2012) explained that employee empowerment is not only the power or freedom to perform any job, but at the same time employees are held more responsible and be accountable. In addition, Shin and Hur (2019) defined empowerment as sharing information and autonomy among employees in decision making.

Job stability refers to an employee's perception about permanency and certainty to continue work in the organization (Liu, Huang, Wang, \& Liu, 2017), where it is a condition in which organizations are providing a permanent working opportunity for employees. Similarly, Daud (2017) defined that employment stability as a condition in which employees feel certainty of their work in the organization.

Working environment is considered one of the main key factors for employee engagement in higher education sector. The working environment implies an environment, culture or climate where employees are fulfilling their duties in the organization (Danish, Ramzan, \& Ahmad, 2013). Working environment is the combination of physical and psychological aspects that help employees to feel comfortable in the workplace (Turker, 2009).

\section{Underpinning Theory}

This study applied SET as it can provide a better theoretical explanation regarding the relationship between ICSR practices and employee engagement. Theoretically, SET refers to the social behavior in terms of an exchanging procedure (Blau, 1964) where one party voluntarily provides benefits to another, and another party will oblige to provide benefits in return (reciprocal relationship) (Gergen, 1969). In this exchange, if employees are satisfied where they are working, in return, the organization potentially gain the support of the employees to bring good performance for the organization.

\section{CSR Practices and Related Outcome Variables}

Santoso (2014) carried out a study to investigate the impact of ICSR towards employee engagement and affective commitment in the hospitality industry. The elements of ICSR comprised of training and education, health and safety, human rights, work-life balance, and workplace diversity. The finding indicated that health and safety were the major predicting factor that affecting employee engagement and affective commitment. On the contrary, a study of employees in HEI by Toh, Chua, Bahron and Abdul Rahim (2017) found that training and education is an integral factor of employee engagement, which congruent with the findings of (Okechukwu, 2017). Supportively, Chaudhary and Bhaskar (2016) highlighted that, in universities, faculties which are active in employee training are capable of improving their services and can secure employee engagement. 
In addition, Manimegalai and Baral (2018) conducted a study on 486 Malaysian hotel employees and the findings showed that job satisfaction partially mediates the relationship between ICSR practices and employee engagement. Another study by Fu, Ye, and Law (2014) found that ICSR practices influence employee engagement through the mediating effects of job satisfaction.

Chaudhary (2019) examines the perception of employees on CSR and employee engagement through psychological meaningfulness, safety, and availability. The sample consist of 187 business professionals. The results revealed that CSR positively influenced employee engagement. In addition, psychological conditions of meaningfulness, safety and availability, fully mediated the relationship of CSR with employee engagement.

Within the Asian context, Peong (2019) examined the impact of CSR and talent management on employee engagement in a water company in Indonesia which consist of 120 employees. The findings found that CSR and talent management program have a positive and significant impact to increase employee engagement. This is congruent with the study done by Al-Tit and Hunitie (2015), who also found that employee engagement can mediate ICSR and job satisfaction among university employees in Jordan.

Duthler and Dhanesh (2018) examined relationship among employees' perception of ICSR communication and employee engagement in the United Arab Emirates. The findings revealed that internal communication of CSR, strongly predicted employee engagement.

Al-Amri, Das and Ben-Ayed (2019) investigated the impact of perceived CSR and employee engagement in Qatar (government, semi-government, and private sectors). The study utilized Stakeholder's Theory focused on employees, customers, government, and society at large. The results revealed that both CSR in the contexts of society and employees affect organizational engagement, whereas CSR in the context of customers affects job engagement. However, CSR within the scope of government is not significantly related to employee engagement. Based on the discussion, this gives an implication that CSR may be a contributing factor to sustain motivated and passionate employees.

In Greece, Tsourvakas and Yfantidou (2018) intended to investigate the impact of CSR on employee engagement, motivation and job satisfaction of two prominent brands, namely Unilever and Porter \& Gamble. The findings revealed that employees of the companies are proud to identify themselves with the companies that are socially responsible and CSR was found positively related to the engagement of employees.

Obeidat (2016) aims to explore the relationship between CSR, employee engagement, and organizational performance in the telecommunication sector. The results of 350 respondents revealed that there is a significant positive relationship between CSR (internal and external) and employee engagement. In addition, the results also showed that employee engagement fully mediated the relationship between CSR and organizational performance.

Based on the findings of different studies in the service industry, it is found that service firms are 
adopting four (4) core dimensions of ICSR practices, namely education and training, employee empowerment, employment stability, and working environment (Lee, Kung, Ong, Seah, \& Yeoh, 2015; Mory et al., 2015). Similarly, a study on Romanian universities showed that for sustainability, three (3) factors, namely working environment, training, and job security are very imperative in the educational system (Grigore, Stancu \& Zaharia, 2013). Therefore, in this study, researchers will cover four (4) prominent dimensions of ICSR practices, which includes training and education, employee empowerment, working environment, and employment stability.

Besides, there are number of studies found that there was a significant relationship between employees' engagement, satisfaction, and working environment (Khan \& Yusoff, 2016; Agbozo, 2017). Similarly, in Pakistan, a study among 1,184 staffs in Pakistan universities reconfirmed that there is a significant connection of engagement in relation to the condition of the workplace (Khan \& Yusoff, 2016). This has further supported Vinerean, Cetina, and Dumitrescu (2013) that the CSR policy is legitimate and appealing to attract talented employees as well as providing a pleasant working environment for the satisfaction of employees.

Furthermore, the results indicated that internal CSR can help to reduce the employee's turnover intention. This can be explained that the value and benefits of internal CSR practices will help to increase employees' loyalty and make them more dedicated toward their jobs.

Based on the discussion above, therefore, this study hypothesizes that:

$\mathbf{H}_{1}$ : There is a positive relationship between Internal CSR practices and employee engagement. $\mathbf{H}_{1 \mathrm{a}}$ : There is a positive relationship between training \& education and employee engagement. $\mathbf{H}_{\mathbf{1 b}}$ : There is a positive relationship between employee empowerment and employee engagement. $\mathbf{H}_{1 \mathbf{c}}$ : There is a positive relationship between employment stability and employee engagement. $\mathbf{H}_{\mathbf{1 d}}$ : There is a positive relationship between working environment and employee engagement. $\mathbf{H}_{\mathbf{2}}$ : Internal CSR practices (training and education, employment stability, employee empowerment, working environment) are the predictors of employee engagement.

\section{Methodology}

Research Design

This study employed a quantitative (survey) design, whereby a structured self-administered, anonymous questionnaire was distributed to employees (academic and non-academic) who are currently employed in a private HEI as a unit of analysis. Survey design is deemed a suitable method to apply in this study as it allows the researcher to effectively determine the opinions of respondents about a particular subject from a specific group of people (Babbie, 2016).

Population and Sampling

The sampling technique adopted in this study was purposive sampling. The concept of purposive sampling is focused on subjects who possess a particular characteristic which could be a more ideal help to the research (Etikan, Musa, \& Alkassim, 2016). ICSR is normally a top-down strategy or planning, where not all employees will have knowledge and awareness about it. Hence, this study selects the academic staff and administrative staff with at least degree qualifications. Operational 
employees was currently not included in this study. For the data collection, a structured anonymous questionnaire had been distributed to the employees and generated 93 valid responses. Sekaran and Bougie (2016) emphasized that a sample size ranging from 30 to 500 is sufficient and acceptable for social science studies.

\section{Measurement}

This study comprised of three (3) section. Section A was about the demographic profiles of the respondents such as gender, staff, nationality, race, level of education, and tenure. Section $B$ regards the dimension of ICSR practices, where the items for training and education was adapted from (AIbdour, Ali, Nasruddin, \& Soh, 2010; Lee \& Bruvold, 2003), employee empowerment, employees' stability, and working environment were adapted from Mory et al., (2015). Section C is about employee engagement which adapted from Al-bdour et al., (2010).

In this study, 5 points Likert-type scale is used for all the latent variables, where 1 represents strongly disagree, 2 indicates Disagree, 3 represents Slightly Agree, 4 indicates Agree, and 5 represent Strongly Agree. Respondents are given freedom to express their views on the series of items about the ICSR practices of the university.

Pilot testing

A pilot study was conducted to test the reliability as well as the accuracy and consistency of the instrument. A total of 30 respondents consisting of employees from one of the public HEls were chosen. According to Hair, Celsi, Money, Samouel \& Page (2015), the reliability analysis scale can be accepted if the Cronbach's alpha coefficient is between 0.6 and 1.0. Hence, the Cronbach's alpha value for the current study ranged from .935 to .957 (Table 1) which is highly accepted and reliable.

Table 1: Cronbach's alpha value of the variables

\begin{tabular}{lccc}
\hline \multicolumn{1}{c}{ Variable(s) } & $\begin{array}{c}\text { No. of } \\
\text { items }\end{array}$ & $\begin{array}{c}\text { Cronbach's Alpha } \\
\text { Value } \\
\text { (Pre-Test, } \mathbf{n = 3 0 )}\end{array}$ & $\begin{array}{c}\text { Cronbach's Alpha } \\
\text { Value } \\
\text { (Post-Test, } \mathbf{n = 9 3 )}\end{array}$ \\
\hline ICSR Practices & 8 & & \\
Training and education & 5 & .948 & .898 \\
Employment stability & 5 & .957 & .926 \\
Employees empowerment & 6 & .941 & .921 \\
Working environment & & .935 & .908 \\
Employee engagement & 4 & & .949 \\
\hline
\end{tabular}

Before the multivariate analysis can be carried out, the data should be normally distributed, as normality is an important requirement in multivariate analysis (Hair, Black, Babin, \& Anderson, 2018; Tabachnick \& Fidell, 2013). Based on Table 2, the values for skewness and kurtosis for independent and dependent variables are in the range between -2 to +2 , with $5 \%$ of sampling error which is considered acceptable to prove normal distribution exists (Tabachnick \& Fidell, 2013). Hence, the current data are still normally distributed and the requirements for multivariate analysis are met. 
INTERNATIONAL JOURNAL OF ACADEMIC RESEARCH IN BUSINESS AND SOCIAL SCIENCES Vol. 10, No. 5, May, 2020, E-ISSN: 2222-6990 @ 2020 HRMARS

Furthermore, multiple regression analysis was also sensitive to multicollinearity problem. According to Tabachnick and Fidell (2013), multicollinearity happens when the independent variables are highly interrelated 0.9 and above. Hence, Variance Inflation Factor (VIF) and tolerance levels are used to examine the multicollinearity problems via the regression result from the SPSS. As Hair et al. (2018) said that the VIF should not exceed 10 and the tolerance values are supposed to be more than 0.10 . Based on Table 3, it showed that the range of tolerance was between .292 till .550 which more than 0.10. On the other hands, the VIF range was from $1.818-3.427$ which is a reasonably because it is less than 10 (Tabachnick \& Fidell, 2013). Thus, it can be concluded that there is no multicollinearity issue among the independent variables in the current study.

Table 2: Skewness and kurtosis of the variables

\begin{tabular}{lcccc}
\hline \multicolumn{1}{c}{ Variable(s) } & Min & Max & Skewness & Kurtosis \\
\hline ICSR Practices & & & & \\
Training and education & 8.00 & 40.00 & -1.150 & 1.171 \\
Employment stability & 5.00 & 25.00 & -0.771 & 0.204 \\
Employee empowerment & 5.00 & 25.00 & -0.785 & 0.764 \\
Working environment & 6.00 & 30.00 & -0.654 & 0.131 \\
Employee engagement & 4.00 & 20.00 & -0.527 & -0.100 \\
\hline
\end{tabular}

Table 3: Multicollinearity test based on tolerance and VIF

\begin{tabular}{lcc}
\hline \multicolumn{1}{c}{ Variable(s) } & Tolerance & VIF \\
\hline Training and education & 0.550 & 1.818 \\
Employment stability & 0.298 & 3.355 \\
Employee empowerment & 0.292 & 3.427 \\
Working environment & 0.470 & 2.130 \\
\hline
\end{tabular}

\section{Results \& Discussion}

Table 4 shown the correlations among the variables. Based on Table 4, it was shown that the correlation matrix among the dimensions of ICSR which focused on training and education $(r=.635$, $p<.05)$, working environment $(r=.644, p<.05)$ have positive and moderate relationships with the employee engagement as a dependent variable. In addition, employment stability $(r=.845, p<.05)$ and employee empowerment $(r=.745, p<.05)$ have a positive and high relationships with employee engagement. Hence, all the results are significant in the relationships. Thus, the research hypothesis $\mathrm{H}_{1}, \mathrm{H}_{1 \mathrm{a}}, \mathrm{H}_{1 \mathrm{~b}}, \mathrm{H}_{1 \mathrm{c}}$, and $\mathrm{H}_{1 \mathrm{~d}}$ are accepted. Thus, when employees perceived internal CSR dimensions (training \& education, employment stability, employee empowerment, and working environment) more positively, engagement of employees will increase. 
INTERNATIONAL JOURNAL OF ACADEMIC RESEARCH IN BUSINESS AND SOCIAL SCIENCES

Vol. 10, No. 5, May, 2020, E-ISSN: 2222-6990 @ 2020 HRMARS

Table 4: Correlation test on the relationship between the dimension of ICSR initiatives and employee engagement ( $n=93$ )

\begin{tabular}{|c|c|c|}
\hline \multirow[b]{2}{*}{ Independent variable(s) } & \multicolumn{2}{|c|}{ Employee Engagement } \\
\hline & $r$ & $p$ \\
\hline \multicolumn{3}{|c|}{ Dimension of ICSR Initiatives } \\
\hline Training and education & $0.635^{* *}$ & 0.000 \\
\hline Employees stability & $0.845^{* *}$ & 0.000 \\
\hline Employee empowerment & $0.745^{* *}$ & 0.000 \\
\hline Working environment & $0.644^{* *}$ & 0.000 \\
\hline
\end{tabular}

${ }^{* *}$ Correlation is significant at the 0.01 level (1-tailed)

This study applied stepwise regression as it is a way to build a model by adding or subtracting predictor variables, where the variables are added or removed based on the test statistics (t-test/ Ftest) of the estimated coefficients to choose the best predictor variables (Stephanie, 2015). ANOVA test for multiple regression analysis (step-wise method) shows that there is a significant relationship between a dependent variable (employee engagement) and independent variables (ICSR) at the 0.05 significance level. The analysis in Table 5 shows that the employee stability of ICSR dimension (Model 1 ) gives a significant result with $F=226.31, p<0.05$. Similarly, the combination of employee stability and education $\&$ training of ICSR dimension (Model 2 ) also gives a significant result ( $F=123.05, p<$ 0.05).

Meanwhile, multiple regression analysis indicates that employee stability significantly contributes $71.0 \%$ of the variance (Adj $R^{2}=0.710$ ) towards employee engagement of the total of 93 respondents in the study. This means that employee stability $(\beta=0.845, p<0.05)$ is the main predictor that cause employees to have high engagement. Moreover, with the combination of employee stability $(\beta=$ $0.734, p<0.05)$ and training \& education $(\beta=0.176, p<0.05)$ as predictors, the contribution value of variance towards employee engagement has increased to $72.6 \%$. Therefore, the increment is $1.6 \%$ (72.6-71.0). Elements which do not significantly contribute to this study are employee empowerment and working environment. Therefore, $\mathrm{H}_{2}$ is partially supported as not all the independent variables are the predictors of employee engagement.

Hence, it can be concluded that there are some other variables $(27.4 \%)$ that are currently not being investigated in this study and they can contribute to the increase of employee engagement. 
INTERNATIONAL JOURNAL OF ACADEMIC RESEARCH IN BUSINESS AND SOCIAL SCIENCES Vol. 10, No. 5, May, 2020, E-ISSN: 2222-6990 @ 2020 HRMARS

Table 5: Regression coefficient of independent variables: Multiple regression analysis, Stepwise Method

\begin{tabular}{|c|c|c|c|c|c|}
\hline Model & & B & Beta & $\mathbf{t}$ & $p$ \\
\hline \multirow[t]{2}{*}{1} & (Constant) & 1.454 & & 1.751 & 0.083 \\
\hline & $\begin{array}{l}\text { Employee } \\
\text { stability }\end{array}$ & 0.726 & 0.845 & 15.046 & 0.000 \\
\hline$F=226.391$, & $d f=1,91$ & $p=0.000$ & $\mathrm{R}=0.845$ & $R^{2}=0.713$ & $\Delta R^{2}=0.710$ \\
\hline \multirow[t]{3}{*}{2} & (Constant) & -0.578 & & -0.507 & 0.613 \\
\hline & $\begin{array}{l}\text { Employees } \\
\text { stability }\end{array}$ & 0.631 & 0.734 & 10.510 & 0.000 \\
\hline & $\begin{array}{l}\text { Training and } \\
\text { education }\end{array}$ & 0.124 & 0.176 & 2.524 & 0.013 \\
\hline$F=123.065$, & $d f=2,90$ & $p=0.000$ & $R=0.856$ & $R^{2}=0.732$ & $\Delta R^{2}=0.726$ \\
\hline
\end{tabular}

This research examined the relationship between the dimensions of ICSR and employee engagement. The finding of the study reveals that four (4) dimensions of ICSR, namely training and education, job stability, empowerment, and working environment have a positive and significant relationship with employee engagement. This is in line with the findings of numerous past studies (Santoso, 2014; Duthler \& Dhanesh 2018; Al-Tit \& Hunitie; 2015; Fu et al., 2014). Further, Pereira, Duarte, and Trindade (2015) emphasized that work engagement is the consequences of employees' perceptions about workplace CSR.

In addition, multiple regression analysis showed that employment stability is the strongest predictor for engagement. The notion therefore implies that the employees who perceived their institutions having good ICSR practices (education and training, employment stability, employee empowerment, and working environment) will be more likely to show a high level of engagement. This further implies that job stability gives comfort, support, and security for the employees (Mory et al., 2015).

The study also showed that there is a significant and positive relationship of training and education with employee engagement. This finding was in line with the results of previous studies (Sendawula, Kimuli, Bananuka, \& Muganga, 2018, Mmako \& Schultz, 2016).

In addition, the current results were congruent with the study of Nawaz, Hassan, Hassan, Shaukat and Asadullah (2014) who found that employee engagement partial mediates the relationship between training, empowerment and employee creativity. Based on the discussion, this implies that employees will engage more with the organization when the organization allow employees to exercise their decision without coercion. As the current organization under study is in HEls, therefore, it is pivotal for the employees to be creative and innovative in making decision independently.

Companies that provide appropriate education and training, in turn, the employees will be able to accomplish tasks or mission that assigned by the institution. Likewise, Esmaeelinezhad, Singaravelloo and Boerhannoeddin (2015) urged that education and training can reduce high turnover or shifting 
INTERNATIONAL JOURNAL OF ACADEMIC RESEARCH IN BUSINESS AND SOCIAL SCIENCES

Vol. 10, No. 5, May, 2020, E-ISSN: 2222-6990 ㄷ 2020 HRMARS

jobs. Consequently, employees will stay longer, if they perceived the management is concerned about providing relevant training courses to enhance their skills and performance.

The current finding was also supported numerous past studies who found that there is a significant and positive association between working environment and employee engagement (Cavazotte \& Chang, 2016; Khan \& Md. Yusoff, 2016; Thang \& Fassin, 2017; Vineran et al., 2013). A good working environment is acknowledged as constitutional compliance with labor practices. Hence, it can be concluded that a conducive and clean working environment is crucial factor for employees' satisfaction and performance.

However, the study found that empowerment and working conditions were not the predictors for employee engagement. The plausible explanation is that the particular private HEls are often business oriented similar to those corporate/business operations, where many of the communication and instructions are usually top-down and bureaucratic in nature. Hence, there is little space for employee to be innovative and make their own decision in their job task. As for the working environment, the findings were aligned with the study of Bakotic and Babic (2013) who found that, poor working environment and facilities lead to job dissatisfaction and employees are unable to utilize their capabilities in an optimum way.

Based on the above discussion, the institution needs to invest facilities to ensure that the working environment is favorable for the employees. For instance, the institution needs to ensure the facility and infrastructure in the institution are functioning properly, having comfortable working condition, free from harassment, and other improper conduct. Ideally, these health and safety working conditions will make the employees feel more secure and thus will increase their organizational satisfaction and engagement.

\section{Conclusion}

In a nutshell, this study has identified the dimensions of ICSR that are very pivotal in influencing the employees for engagement particularly in the HEls context. By applying the social exchange theory, this research provides a deep understanding of the interrelationship between the dimensions of ICSR practices (education and training, empowerment, job stability, and working environment) and employee engagement. It can be concluded that employees are the asset of an organization, and ICSR practices can maximize the employee engagement as an organization and employees are mutually interdependent (Roza, 2016).

Implications of the Study

The study proposed several managerial implications. Firstly, universities who want to establish beneficial relationship with employees, can practice the ICSR initiatives strategically. The management of the university should perform the most expected dimensions of ICSR and incorporate more interactively to inspire employees for engagement and boost their morale. Hence, among other dimensions ICSR, the management has to take into consideration the prominent factors of ICSR, such as education and training, job security, empowerment, and working environment, to provide an exceptional and memorable working life. 
In addition, HEI is mainly made up of knowledge workforces who are preferably in creativity and innovation, but at the mean time following regulations, procedures that are being set by the institution. Hence, this gives the insights to the top management of the HEI that empowerment and innovative need to be highlighted to better engage with their employees. This will potentially help to enhance the morale of employees and make them to engage and have a sense of belonging to the institution.

Besides, the management of the private $\mathrm{HEI}$ under studied should plan several ICSR related programmes to improve the understanding of ICSR knowledge among the employees. For instance, they can conduct courses or seminars to introduce the employees to the company's CSR policies and programmes, given that CSR is a top-down strategy that not all employees are aware of. The employees should have access to the information related to the human resource practices, such as a training and education that may help promote career advancement. Besides, equal opportunities for promotion based on merits should be applied rather than following bureaucratic management systems that are based on advancement of seniority.

In term of theoretical contributions, the study supported the linkages between SET, ICSR and employee engagement. The mutual relationship is evidence in the findings suggesting that the ICSR initiatives as the input in the SET will help to shape positive employees' perceptions about the company and in return will lead to positive organizational outcomes, such as engagement and retention in the context of HEls.

\section{Limitations and Recommendations for Future Study}

The current study only analyzed a small sample size, whereby the sample is only focused on the employees in one private HEI. Hence, in the future, a larger number of respondents from similar or different universities can be included to enhance the accuracy of the results and able to make generalization.

Additionally, the future research may apply to different industries in Malaysia, such as banking, manufacturing and private and non-profit organizations (NGOs) as well. Along with, future studies that look at comparison between the ICSR initiatives practiced by both public and private universities to add wider categorical information and understanding related to ICSR.

This study has only studied four dimensions of ICSR, but other variables that can influence employees for engagement, such as, work-life balance, organizational commitment, job satisfaction, employeremployee relationship, and leadership styles can be included in the future. This study also suggests a possible test of the mediating and moderating effects of these variables.

In terms of methodology, the current study only uses quantitative survey method to analyze the dimensions of ICSR practices and employee engagement. Future research can employ qualitative approaches; such as interviews or mix-mode method to complement the deficiency of the quantitative approach. The integration of quantitative (survey) and qualitative methods (in-depth interviews) will provide depth information regarding this area and yield better results. It is also recommended that for better understanding, future researchers can conduct a longitudinal study. It 
INTERNATIONAL JOURNAL OF ACADEMIC RESEARCH IN BUSINESS AND SOCIAL SCIENCES

Vol. 10, No. 5, May, 2020, E-ISSN: 2222-6990 @ 2020 HRMARS

will show the changes over time regarding the relationship between ICSR practices and employee engagement.

\section{Acknowledgement}

The early version of the work has been presented and included in the conference proceeding of International Conference on Communication, Language, Education, and Social Sciences (CLESS) 2019; Multimedia University (MMU).

\section{References}

Albdour, A. A., Ali, A., Nasruddin, E., \& Soh, K. L. (2010). The relationship between internal corporate social responsibility and organizational commitment within the banking sector in Jordan. International Scholarly and Scientific Research \& Innovation, 4(7), 852-871.

Al-Tit, A. A., \& Hunitie, M. (2015). The mediating effect of employee engagement between its antecedents and consequences. Journal of Management Research, 7(5), 47-62.

Al-Amri, F. H., Das, A., \& Ben-Ayed, O. (2019). The impact of perceived corporate social responsibility on employee engagement: The case of Qatar. Business Strategy and Development, 2, 180191. doi: $10.1002 /$ bsd2.52

Agbozo, G. K. (2017). The effect of work environment on job satisfaction: Evidence from the banking sector in Ghana. Journal of Human Resource Management, 5(1), 12-18.

Azmin, M. T. (2016). Corporate social responsibility and employee behavior: Mediating role of organizational commitment. Review of Business Management, 18(60), 207-225.

Babbie, E. R. (2016). The practice of social research (14 ${ }^{\text {th }}$ ed.). Cengage Learning

Bailey, C., Madden, A., Alfes, K., \& Fletcher, L. (2017). The meaning, antecedents and outcomes of employee engagement: A narrative synthesis. International Journal of Management Reviews, 19(1), 31-53.

Bakar, R., \& Ismail, A. (2019). Sustainability of higher education: A global perspective. Pulau Pinang: Penerbit Universiti Sains Malaysia.

Bakotic, D., \& Babic, T. B. (2013). Relationship between working conditions and job satisfaction: The case of Croatian ship building company. International Journal of Business and Social Science, 4(2), 206-213.

Blau, P. M. (1964). Exchange and power in social life. New York: John Wiley \& Sons.

Cavazotte, F., \& Chang, N. C. (2016). Internal corporate social responsibility and performance: A study of publicly traded companies. BAR - Brazilian Administration Review, 13(4), 64-94.

Chan, T. J., \& Hasan, M. N. A. (2018). Corporate social responsibility practices from the employees' perspective: A case of Malaysian higher education institution. International Journal of Academic Research in Business and Social Sciences, 8(4), 131-153.

Chang, D. W., Sirat, M., \& Abdul Razak, D. (2018). Education in Malaysia towards a developed nation. Economics Working Paper, 3(5), 1-19. Retrieved from https://www.iseas.edu.sg/images/pdf/ISEASEWP2018-4Wan.pdf

Chaudhary, N. S., \& Bhaskar, P. (2016). Training and development and job satisfaction in education sector. International Journal of Business Quantitative Economics and Applied Management Research, 2(8), 89-97.

Chaudhary, R. (2019). Corporate social responsibility perception and employee engagement: Role of psychological meaningfulness, safety and availability. Corporate Governance, 19(4), 631-647. 
INTERNATIONAL JOURNAL OF ACADEMIC RESEARCH IN BUSINESS AND SOCIAL SCIENCES

Vol. 10, No. 5, May, 2020, E-ISSN: 2222-6990 @ 2020 HRMARS

Curran, S. R. (2012). Assessing employee turnover in the Language Services Section of Parliament of the Republic of South Africa. Unpublished Master's Thesis. University of Stellenbosch.

Danish, R.Q., Ramzan, S., \& Ahmad, F. (2013). Effect of perceived organizational support and work environment on organizational commitment: Mediating role of self-monitoring. Advances in Economics and Business, 1(4), 312-317.

Daud, N. (2017). Job security and well-being among private workers in Malaysia. Journal of Technology Management and Business, 4(1), 25-42.

Duthler, G., \& Dhanesh, G. (2018). The role of corporate social responsibility (CSR) and internal CSR communication in predicting employee engagement: Perspectives from the United Arab Emirates (UAE). Public Relations Review, 44(4), 453-462. doi.org/10.1016/j.pubrev.2018.04.001

Esmaeelinezhad, O., Singaravelloo, K., \& Boerhannoeddin, A. (2015). Linkage between perceived corporate social responsibility and employee engagement: Mediation effect of organizational identification. International Journal of Human Resource Studies, 5(3), 174-190.

Etikan, I., Musa, S. A., \& Alkassim, R. S. (2016). Comparison of convenience sampling and purposive sampling. American Journal of Theoretical and Applied Statistics, 5(1), 1-4.

$\mathrm{Fu}, \mathrm{H} .$, Ye, B., \& Law, R. (2014). You do well and I do well? The behavioral consequences of corporate social responsibility. International Journal of Hospitality Management, 5(1), 1319-1329.

Gao, J. H. (2019). Examining corporate social responsibility and employee engagement in Macao. International Journal of Business and Management, 12(3), 1380-1402.

Gergen, K. J. (1969). The psychology of behavior exchange. Addison Wesley Publishing Company, Reading, MA.

Grigore, G. F., Stancu, A., \& Zaharia, R. M. (2013). Challenges of integrating CSR into curricula: An analysis of the Romanian educational system. Education and Corporate Social Responsibility: International Perspectives, 4(1), 223-242.

Hair, J.F., Celsi, M., Money, A., Samouel, P., \& Page, M. (2015). Essential of business research methods. ( $3^{\text {rd }}$ ed.). New York: Routledge.

Hair, J. F., Black, W. C., Babin, B. J., \& Anderson, R. E. (2018). Multivariate data analysis (8 ${ }^{\text {th }}$ ed.). Cengage Learning EMEA.

Khan, A., \& Md. Yusoff, R. (2016). A study on dynamic links between resources, work engagement and job performance in academia of Pakistan. International Review of Management and Marketing, 6(3), 544-550.

Lee, C. H., \& Bruvold, N, T. (2003). Creating value for employees: Investment in training and education. International Journal of Human Resource Management, 14(6), 981-1000.

Lee, I. Y. C., Kung, L. Y., Ong, H. P., Seah, Y. Z., \& Yeoh, P. P. (2015). Does corporate social responsibility affects employees' quality of work life? A study on Malaysian service firms. (Unpublished Bachelor's thesis). Universiti Tunku Abdul Rahman

Liu, X., Huang, Q., Wang, H., \& Liu, S. (2017). Employment security and employee organizational citizenship behavior: Does an 'iron rice bowl' make a difference? The International Journal of Human Resource Management, 1(3), 1-20.

Low, M. P. (2020). The divergent influence of social responsibility on employee engagement through the lens of marital status: Evidence from higher education institutions. Review of Business Management, 22(2), 205-231. 
INTERNATIONAL JOURNAL OF ACADEMIC RESEARCH IN BUSINESS AND SOCIAL SCIENCES

Vol. 10, No. 5, May, 2020, E-ISSN: 2222-6990 @ 2020 HRMARS

Mmako, K., Schultz, C. (2016). An employee engagement framework for technical vocational education and training colleges in South Africa. South African Journal of Higher Education, 30(2), 143-163. doi.org/10.20853/30-2-606

Manimegalai, S., \& Baral, R. (2018). Examining the mediating role of organizational trust in the relationship between CSR practices and job outcomes. Social Responsibility Journal, 14(3), 433-447. doi.org/10.1108/SRJ-01-2017-0007

Manogharan, M. W., Thivaharan, T., \& Abd Rahman, R. (2018). Academic staff retention in private higher education institute - case study of private colleges in Kuala Lumpur. International Journal of Higher Education, 7(3), 52-78.

Hasan, M. N. (2017). Managing standards in corporate social responsibility online: A case study of a Malaysian higher learning institution. International Journal of Economic Research, 12(21), 249-274.

Mory, L., Wirtz, B. W., \& Göttel, V. (2015). Factors of internal corporate social responsibility and the effect on organizational commitment. The International Journal of Human Resource Management, 27(13), 1393-1425.

Nawaz, M. S., Hassan, M., Hassan, S., Shaukat, S., \& Asadullah, M. A. (2014). Impact of employee training and empowerment on employee creativity through employee engagement: Empirical evidence from the manufacturing sector of Pakistan. Middle-East Journal of Scientific Research, 19(4), 593-601.

Obeidat, B. Y. (2016). Exploring the relationship between corporate social responsibility, employee engagement, and organizational performance: The case of Jordanian mobile telecommunication companies. International Journal of Communications, Network and System Science, 9, 361-386. doi: 10.4236/ijcns.2016.99032

Okechukwu, W. (2017). Influence of training and development, employee performance on job satisfaction among the staff of School of Technology Management and Logistics, Universiti Utara Malaysia (STML, UUM). Journal of Technology Management and Business, 4(1), 1-16.

Pelochino, M. (2017). Redefining Professional Development for Teachers. Retrieved July, 2019, from https://nearpod.com/blog/disrupting-teacher-professional-development-one-workshoptime/

Peong, H. K. (2019). The effect of corporate social responsibility and talent management on employee engagement: A Study at Tirta Komodo Regional Water Company, East Nusa Tenggara, Indonesia in International Conference on Economics, Education, Business and Accounting, KnE Social Sciences, 967-981.

Pereira, A., Duarte, A., \& Trindade, G. (2015). The relationship between the employees' perceptions of CSR, work engagement and human values. Responsibility and Sustainability Socioeconomic, political and legal issues, 3(2), 27-35.

Pham-Thai, N. T., McMurray, A. J., Muenjohn, N., \& Muchiri, M. (2018). Job engagement in higher education. Personnel Review, 47(4), 951-967.

Ramasamy, V., \& Abdullah, N. H. (2017). Faculty's turnover in private higher learning Institutions: A phenomenal inquiry. BEH Business and Economics Horizon, 13(2), 169-181.

Ranjan, S., \& Yadav, R. S. (2018). Uncovering the role of internal CSR on organizational attractiveness and turnover intention: The effect of procedural justice and extraversion. Asian Social Science, 14(12), 76-85. 
INTERNATIONAL JOURNAL OF ACADEMIC RESEARCH IN BUSINESS AND SOCIAL SCIENCES

Vol. 10, No. 5, May, 2020, E-ISSN: 2222-6990 @ 2020 HRMARS

Rathakrishnan, T., Ng, S. I., \& Tee, K. K. (2016). Turnover intentions of lecturers in private universities in Malaysia. Pertanika Journal of Social Science \& Humanities, 24(S), 129-146.

Roza, L. (2016). Employee engagement in corporate social responsibility. (Unpublished Doctoral Thesis). Erasmus University, Rotterdam.

Sani, R., \& Mustafa, Z. (2019). What lies ahead in 2019 for higher education? New Straits Times. Retrieved from https://www.nst.com.my/education/2019/01/446228/what-lies-ahead2019-higher-education.

Santoso, I. L. (2014). The impact of internal CSR towards employee engagement and affective commitment in XYZ hotel Surabaya. Business Management, 2(2), 79-88.

Saraih, U. N., Zin Aris, A. Z., Sakdan, M. F., \& Ahmad, R. (2017). Factors affecting turnover intention among academician in the Malaysian higher educational institution. Review of Integrative Business \& Economics Research, 6(1), 1-15.

Sekaran, U., \& Bougie, R. (2016). Research methods for business: A skill building approach $\left(7^{\text {th }}\right.$ ed.).New Jersey: John Willey and Sons, Inc.

Sendawula, K., Kimuli, S. N., Bananuka, J., \& Muganga, G. N. (2018). Training, employee engagement and employee performance: Evidence from Uganda's health sector. Cogent Business \& Management, 5, 1-12. doi.org/10.1080/23311975.2018.1470891

Shin, Y., \& Hur, W. (2019). When do service employees suffer more from job insecurity? The moderating role of coworker and customer incivility. International Journal of Environmental Research and Public Health, 16(7), 1298-1315.

Slack, R. E., Corlett, S., \& Morris, R. (2015). Exploring employee engagement with (corporate) social responsibility: A social exchange perspective on organizational participation. Journal of Business Ethics, 127, 537-548.

Stephanie. (2015). Statistics How To. Retrieved on March, 13, 2020 from https://www.statisticshowto.datasciencecentral.com/stepwise-regression/

Tabachnick, B. G., \& Fidell, L. S. (2013). Using Multivariate Statistic: Pearson New International Edition (6 $6^{\text {th }}$ ed.). Boston: Pearson Education Inc

The Star. (2018). Redesigning Malaysia's higher education system. Retrieved on October 14, 2019 from https://www.thestar.com.my/news/education/2018/05/06/redesigning-malaysiashigher-education-system

Toh, P. S., Chua, G. S. Y., Bahron, A., \& Abdul Rahim, I. H. (2017). The influence of training, employee engagement and performance appraisal on turnover intention among lecturers in Sabah private higher education institutions. Journal of Global Business and Social Entrepreneurship, 1(3), 89-98.

Tsourvakas, G., \& Yfantidou, I. (2018). Corporate social responsibility influences employee engagement. Social Responsibility Journal, 14(1), 123-137. doi: 10.1108/SRJ-09-2016-0153

Turker, D. (2009). How corporate social responsibility influences organizational commitment. Journal of Business Ethics, 85(2), 189-204.

Vinerean, S., Cetina, I., \& Dumitrescu, L. (2013). Modelling employee satisfaction in relation to CSR practices and attraction and retention of top talent. Expert Journal of Business and Management, 1(1), 4-14.

Zulfiqar, S., Sadaf, R., Popp, J., Vveinhardt, J., \& Máté, D. (2019). An examination of corporate social responsibility and employee behavior: The case of Pakistan. Sustainability, 11, 3515. 